Борислава Р. Ераковић

nsboba@gmail.com

(Филозофски факултет - Англистика, Нови Сад)

\title{
ИНСТРУМЕНТИ ОЦЕЊИВАҢА ПРЕВОДИЛАЧКЕ КОМПЕТЕНЦИЈЕ У НАСТАВИ
}

\section{САЖЕТАК}

Вредновање преводилачке способности студената у нашим условима углавном је засновано на сумативном оцењивању превода непознатог текста у испитним условима, и то на основу анализе грешака. При томе се анализирају два типа грешака: разумевање изворног текста и нарушавање језичких правила (граматичких, лексичких и прагматичких) у циљном тексту. Како је у студијама о актуелним начинима вредновања превода показано, са педагошког становишта ефикаснији су они модели вредновања превода којима се установљује које су преводилачке поткомпетенције узрок насталих грешака. На основу консултоване литературе из области предагогије стручног превођења и вишегодишњег педагошког преводилачког искуства, у раду описујемо могућу примену преводилачког дневника и превода текста у слободним условима као могуће инструменте за вредновање укупне преводилачке компетенције студената на курсевима превођења стручних текстова.

КЉУЧНЕ РЕЧИ: оцењивање, преводилачка компетенција студената, превод у слободним условима, преводилачки дневник, коментар вршњачког превода. 
$\theta$ сновни инструмент за оцењивање преводилачке компетенције обично је превод непознатог текста у испитним условима. ${ }^{1)}$ Студент нема приступ интернету нити другим изворима информације сем једнојезичким речницима и превод пише руком. Такви испитни услови се веома разликују од услова у току рада на курсу, као и од редовних услова рада касније у професионалном животу, када су студентима доступни сви извори иноформација, посредни и непосредни, електронски и папирни, а превод се ради у неком од програма из Мајкрософтовог пакета за рад на тексту. Критерујуми у оцењивању испитних превода стога су последично базирани на анализи броја и врсте језичких грешака у студентском преводу. Уколико се, међутим, жели вредновати укупна постигнута преводилачка компетенција или ставити тежиште на оне аспекте преводилачке компетенције који се доминантно развијају на курсу, потребно је укључити још неке инструменте и методе оцењивања.

Дефинисање преводилачке компетенције као скупа поткомпетенција омогућава конкретизовање практичних педагошких питања релевантних за образовање/ обуку преводилаца, од формулације циљева, жељених и очекиваних исхода, до вредновања знања и умећа студената. Према холистичкој дефиницији истраживачке групе Пакте (Pacte 2003:58-59, 2011: 2), преводилачка компетенција је „систем неопходних знања и вештина за обављање преводилачке делатности" и састоји се од пет поткомпетенција: билингвалне, ванјезичке, инструменталне, стратешке и стручне (тј. познавања преводилачких појмова и принципа) и психофизиолошке компоненте. За потребе образовања преводилаца на нивоу основних студија, Кели (Kelly 2005:33) том списку додаје и интерперсоналну компетенцију ${ }^{2)}$. Двојезичком и

1) На испитима из превода са енглеског студенти имају задатак да за деведесет минута преведу непознат текст дужине од 250 до 300 речи, при чему на располагању имају једнојезичне речнике.

2) Преводилачку компетенцију различити аутори различито дефинишу у зависности од контекста и циља проучавања компетенција и то је још увек актуелно питање у преводилачким студијама. Како је наш контекст педагошки, одабрали смо модел компетенције чији је настанак мотивисан потребама образовања преводилаца. Кели (2005: 33-34) наводи све компетенције као и истраживачи Пакте мада их другачије именује као комуникативну, културну, предметну, инструменталну и психофизиолошку компетенцију, али додаје и интерперсоналну, која је са становишта развијања способтости студената да се по завршетку студија на адекватан начин укључе у професионалну заједницу и по нашем мишљењу веома важна. ванјезичком поткомпетенцијом владају и преводиоци и билингвалне особе. Преводилачка компетенција се квалитативно разликује од „природне способности превођења" (Harris i Sherwood 1978 према Pacte 2003:57) коју поседују све билингвалне особе, и то захваљујући инструменталној, стручној и стратешкој поткомпетенцији. Имајући у виду да је један од циљева акредитованог програма основних студија Еніллескої језика и књижевносиии стицање компетенција за йрофесије које су не-

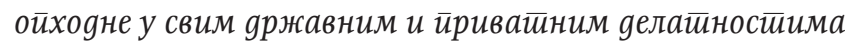
у којима се указује йойреба за йрево ииоиима енілеской језика (2009: 5), дакле овладавање свим аспектима преводилачке компетенције, целовито вредновање постигнућа студената на преводилачким курсевима требало би да, осим вредновања билингвалне поткомпетенције путем анализе језичких грешака у преводу, обухвати и друге поткомпетенције.

Анализом језичких грешака у преводу проверава се способност студената да разумеју изворни текст и преформулишу га на циљном језику. Ту се најчешће ради о сумативном оцењивању, које студенту показује којим аспектима језичке преводилачке компетенције не влада у довољној мери (познавање лексике и граматике изворног језика, способност раздвајања изворног и циљног језика у превођењу и вештина писања на циљном). Проблеми са оваквим моделом су вишеструки (Kelly 2005:132), а овде наводимо два која према нашем искуству најзначајније утичу на ефикасност и позитиван учинак оцењивања: недовољна повезаност са исходима наставе и нерепрезентативност стечених знања.

\section{Недовољна повезаност са исходима наставе}

У традиционалним спитним условима, када студенти немају приступ интернету ни довољном броју језичких и терминолошких приручника, не може се оценити усвојеност компетенција које су за превођење стручних текстова веома важне. Превод студената показује готова решења, не и пут који је до њих водио, а са становишта сагледавања усвојености поткомпетенција то је само половина информације. На стручним преводилачким курсевима, посебно је важно у области инструменталне компетенције, оценити како студенти решавају проблеме у размевању изворног стручног текста, тј. да ли умеју 
да пронађу адекватне папирне и електронске, посредне и непосредне изворе информација како би стекли неопходна знања и колико су у томе ефикасни, тј. колико времена им таква активност одузима. Важан аспект преводилачке компетенције је и психофизиолошки елемент мотивисаности, радозналости, посвећености и истрајности у решавању проблема, тј. да ли су спремни да уложе потребан труд и време како би разумели текст и пронашли решење. У погледу стратешке поткомпетенције, важно је утврдити и да ли студенти поред језичких, препознају и прагматичке проблеме у тексту, којим се принципима руководе у њиховом решавању, као и да ли их решавају интуитивно или аналитички. Иста се компетенција манифестује и у способности уочавања и исправљања сопствених грешака у преводу.

На основу неадекватног лексичког решења у студентском преводу најчешће се не може са сигурношћу закључити да ли је студент проблем решавао интуитивно, као језички непознат израз, или је био свестан и прагматичке, текстуалне и ванјезичке стране проблема. Такође, врло је релевантна информација и да ли је у сагледавању прагматичких аспеката студент превидео неке од важних фактора или је био руковођен другим функционалним разлозима, па се не може проценити ни адекватност одабране стратегије. Другим речима, потребно је поред превода, имати увид и у процес превођења током ког се непосредно испољавају циљане поткомпетенције и евентуалне грешке у преводу сагледавати као одраз усвојених односно неусвојених компетенција.

\section{Превод текста у испитним условима није репрезентативан показатељ усвојених знања}

Као што је свима који предају на преводилачким курсевима добро познато, одрећен број студената у свакој генерацији, и без икакве обуке, има способност раздвајања језика̂ и мање је подложан утицају интереференције из изворног у циљни језик. Та способност, која се у преводу манифестује природним и флуентним изразом, као једна од компонената билингвалне поткомпетенције, јесте неопходан, али не и довољан услов за квалитетно превођење стручних текстова, и не говори ништа о осталим аспектима (прагматич- ком, текстуалном, социолингвистичком) исте поткомпетенције који се очитују, на пример, у способности да се пронађу адекватна прагматичка и културолошка решења у циљном тексту, или да се део изворника адаптира или сажме у складу са функционалним критеријумима и потребама примаоца превода. Врло важан аспект језичке поткомпетенције јесте и способност анализе типа текста ком превод треба да припада и уочавање његових доминантних циљних интертекстуалних одлика. Тешкоћа у овладавању стручном терминологијом не састоји се само у утврђивању терминолошких еквивалената, већ, како је у литератури (Baumgartner 1994:296) добро познато, и у познавању колокацијског потенцијала одређеног термина и његове одговарајуће употребе на нивоу синтагме. Да би се вредновао тај аспект језичке компетенције, студенту је потребно време и могућност тражења илустративних (тј. паралелних) текстова у циљном језику у којима су термини правилно употребљени. Јасно је да се такав задатак не може обавити у традиционалним испитним условима. Према нашем искуству, постизање текстуалности у циљном тексту један је од најтежих аспеката преводилачке делатности којим студенти треба да овладају и који се стиче током целог трајања курса, па стога, иако јесте елеменат формативног оцењивања, не може бити и елеменат континуираног оцењивања и на тај начин утицати на формирање крајње оцене. Како се тип и тежина текста за превод на испиту најчешће прилагођавају процењеној максималној способности студената да у традициноналним испитним условима схвате и преведу одређени текст, за испит се обично бирају текстови у којима нема проблема који би захтевали додатно истраживање и консултовање паралелних текстова. У превођењу таквих текстова стога и не може доћи до изражаја способност решавања прагматичких, социолингвистичких и ванјезичких проблема.

\section{Инструменти за свеобухватније оцењивање преводилачке компетенције}

Комплементарни типови задатака за проверу инструменталне и стратешке компетенције, као и психофизиолошког елемента, у стручној литератури одавно су познати. Од укупног броја бодова које студент стиче 
на курсу, део може да буде стечен преводом у слободним условима, када студенти имају на располагању одређен дужи временски период (24 или 48 часова) и доступне све посредне и непосредне изворе информација. Такав превод треба да буде праћен и детаљним преводилачким дневником у којем ће студент одговарати на питања која наставнику омогућавају да стекне увид y: 1) терминолошке изворе; 2) преводилачке проблеме које је студент препознао; 3) стратегије у њиховом решавању (тј. преводилачке технике које је применио). Поред наведених инструмената, ефикасан показатељ стратешке компетенције јесте и способности процене квалитета превода, па трећи инструмент оцењивања може бити коментар вршњачког превода.

Примена преводилачког дневника и коментара вршњачког превода у циљу вредновања преводилачке компетенције подразумева да су сви аспекти таквих задатака студентима добро познати, тј. да су током курса студенти стекли сазнања о кључним елементима функционалног приступа у вредновању квалитета превода стручних текстова, да су стекли искуство у коментарисању туђих превода као виду неформалног вршњачког оцењивања и професионалне комуникације и да су писали преводилачке дневнике у којима су извештавали о преводилачким проблемима с којима су се сусретали и на одговарајући начин извештавали о стратегијама за које су се одлучивали.

Аспектима примене преводилачког дневника у стручној литератури бавили су се различити аутори и за њега користили различите термине: Гонзалес-Дејвис (Gonzalez-Davies 2005) говори о писаним протоколима, Робинсон (Robinson 2003:270) о преводилачким дневницима, Жил (Gile 1995: 123-124) и Хансен (Hansen 2006) о интегралном извештају о проблемима и стратегијама (Integrated Problem and Decision Reporting). Преводилачки дневник може бити у слободној форми, када се студентима оставља да сами одлуче о броју и врсти проблема о којима ће у дневнику реферисати, може им се дати генерално упутство о броју и типу проблема које треба да забележе или конкретна питања на која треба да дају одговор. Овај инструмент може дати врло прецизне податке наставнику, али његова примена у пракси подразумева добру припремљеност студената у погледу начина на који треба да га пишу и типа информација које у њему треба да забележе.

Уколико је веран приказ процеса превођења, дневник је врло захтеван задатак који тражи исто толико времена колико и сам превод, па је неопходно да студенти разумеју његову сврху и имају одређена минимална теоријска предзнања. Резултати анкете спроведене у јануapy 2008. међу студентима четврте године Англистике, која је имала за циљ да испита став студената у погледу корисности преводилачког дневника у наставном процесу, потврдили су његове позитивне стране, али и да његова примена претпоставља да студенти владају појмовима као што су преводилачки проблем, преводилачка стратегија и преводилачка техника (Hansen 2006: 7, Gonzalez-Davies 2005). Негативни ставови студената у погледу редовне употребе дневника на часовима превођења тицали су се тешкоћа у прецизирању и објашњавању проблема које су имали, и у тим случајевима ни конкретна упутства ${ }^{3)}$ за писање дневника нису се показала корисна, што нам говори да уколико студенти немају представу о појмовима као што су преводилачки проблем, стратегија и техника, преводилачки дневник не може да пружи потребне информације наставнику. Међу позитивним ставовима важна запажања била су да су им дневници које су писали у току курса помагали да размишљају о тексту који су преводили и да је и само вербализовање типа проблема често водило његовом решавању, чак и уколико су писање дневника првобитно сматрали ирелевантним за овладавање потребним знањима и вештинама.

Превод који студент ради у задатом року и уз примену свих доступних извора иноформација и преводилачки дневник стога су комплементарни инструменти који, примењени заједно за формативно оцењивање у току курса омогућавају наставнику да садржаје прилагоди потребама студената, а као инструмент сумативног оцењивања омогућавају студенту да на најбољи начин

3) Као подстицај за писање преводилачког дневника кориштена су питања из инструмента за проверу усвојености преводилачке компетенције групе Пакте (Orozco i Albir 2000): Које сте проблеме имали у превођењу текста? Изаберите пет најважнијих проблема и одговорите на наредна питања, описујући тип проблема и начин на који сте га решавали. Проблем (наведите проблематичан део текста): Решење: Да ли мислите да сте решили проблем? Да $\rightarrow$ Шта сте урадили да бисте га решили? Не $\rightarrow$ Да ли сте покушали да га решите? Не. Да $\rightarrow$ На који начин? 
искаже у којој мери влада текстуалним аспектом језичке компетенције, елементима стратешке компетенције који се тичу одабира стратегија као и терминолошким аспектима инструменталне компетенције.

Битан елеменат преводилачке компетенције који се развија на свим курсевима превођења, јесте и евалуација конкретних резултата у циљном тексту (Hurtado Albir et al. 2002:57), која се може циљано и изоловано вредновати у посебном типу задатка - коментару вршњачког превода. Задатак студената био би да, упоређујући оригинал и превод, препознају грешке, од значењских, текстуалних, прагматичких до ванјезичких, предложе адекватнија решења и образложе их. У таквом задатку пажња студената била би усмерена само на анализу остварених решења у циљном тексту, што омогућава наставнику да адекватно оцени у којој је мери студент овладао текстуалним аспектима језичке компетенције као што су постизање кохерентности и кохезије у циљном тексту, којима студенти традиционално придају најмање пажње када у испитним условима преводе непознати текст.

Истраживања захтева тржишта рада за преводиоце у Европи указала су на потребу да се преводилачка компетенција профилише као скуп релевантних поткомпетенција. Услови у којима се одвија професионална делатност преводилаца данас у нашој земљи битно је другачија од оне која је постојала до краја осамдесетих година прошлог века. Преводилачке агенције су постале доминантан тип послодавца, а услови рада у њима подразумевају спремност и способност да се брзо и ефикасно овладава новим стручним знањима, терминологијом, различитим типовима текстова и електронским преводилачким алатима. Специјализација у превођењу, пожељна у време великих послодаваца који су на неодређено време запошљавали читаве тимове преводилаца, данас често није економски одржива ни за хонорарног преводиоца ни за преводилачку агенцију. Дефинисање исхода наставе преко циљаних преводилачких компетенција омогућава да се одговори на потребу образовања преводилаца способних за перманентно учење и прилагођавање професионалним захтевима, па ту промену нужно морају пратити и методе и инструменти оцењивања учинка наставе и постигнућа студената.

\section{Л И Т Е Р А Т У Р А}

- Baumgartner, P. (1994). Technical Translation: Putting the Right Terms in the Right Context. In: Dollerup, Cay i Annette Lindegaard (eds.) Teaching Translation and Interpreting 2. Amsterdam/Philadelphia: John Benjamins Publishing Company.

- Dokumentacija za akreditaciju studijskog programa: Engleski jezik i književnost, Osnovne akademske studije. Novi Sad. 2009.

(http://www.ff.uns.ac.rs/studijski_programi/EJ0-osnovne.pdf)

- Gile, D. (1995). Basic Concepts and Models for Interpreter and Translator Training. Amsterdam/Philadelphia: John Benjamins Publishing Company.

- Gile, D. (2004). Integrated problem and decision reporting as a translator training tool. The Journal of Specialised Translation 2. (http://www.jostrans.org)

- González D., Scott-Tennent M. i Ch. (2005). A Problem-Solving and Student-Centred Approach to the Translation of Cultural References. Meta 50/1. (http://id.erudit.org/iderudit/010666ar)

- Hansen, G. (2006). Retrospection methods in translator training and translation research. Journal of Specialised Translation 5. (http://www.jostrans.org/issue05/art_hansen.pdf)

- Kelly, D. (2005). A Handbook for Translator Training. Manchester: St Jerome Publishing.

- Orozco, M. (2002). Measurring Translation Competence Acquisition. Meta 47/3.

(http://www.erudit.org/revue/meta/2002/v47/n3/008022ar.pdf)

- PACTE (2003). Building a Translation Competence Model. In: Alves, Fabio (ed.) Triangulating Translation: Perspectives in process oriented research. Amsterdam/Philadelphia: John Benjamins Publishing Company. (http://www.fti.uab.es/pacte/ publicacions/translation_ct_model.pdf)

- PACTE (2011). Results of the Validation of the PACTE Translation Competence Model: Translation Project and Dynamic Translation Index. In: O'Brien, Sh. (ed.) IATIS Yearbook 2010. (u štampi). (http://grupsderecerca.uab.cat/pacte/sites/grupsderecerca.uab. cat.pacte/files/2011_PACTE_Continuum.pdf)

- Robinson, D. (2003). Becoming a Translator, An Introduction to the Theory and Practice of Translation. Routledge.

- Waddington, Ch. (2001). Different Methods of Evaluating Student Translations: The Question of Validity. Meta 46/2. (http://www.erudit.org/revue/meta/2001/v46/n2/004583ar.pdf) 
Borislava R. Eraković

\title{
INSTRUMENTS FOR THE ASSESSMENT OF STUDENT TRANSLATION COMPETENCE
}

\begin{abstract}
Summary
The paper summarizes the main drawbacks of traditional restricted examinations as a method of evaluating student translation competence. It demonstrates how such examination conditions limit the evaluation of student translation competence to the analysis of linguistic errors and explains why this kind of evaluation does not provide an adequate assessment of the textual element of bilingual subcompetence, as well as for the instrumental and strategic translation subcompetences. It then proceeds to demonstrate how additional instruments, such as a peer translation commentary and a take-home translation complemented by a translation diary may be used to cover the full range of subcompetences targeted by a course in technical and scientific translation.
\end{abstract}

Key words: assessment, student translation competence, take-home translations, translation diary, peer translation commentary. 